УДК 621.35

DOI https://doi.org/10.32838/2663-5941/2020.5/28

\title{
Смирнова О.Л.
}

Национальный технический университет «Харьковский политехнический институт»

\section{Пилипенко А.И.}

Национальный технический университет «Харьковский политехнический институт»

\section{АНОДНОЕ ОКИСЛЕНИЕ СПЛАВА $\mathrm{TI}_{6} \mathrm{AL}_{4} \mathrm{~V}$ В РАСТВОРАХ КАРБОНОВЫХ КИСЛОТ}

Представлені результати дослідження процесів електрохімічного окислення титанового сплаву $\mathrm{Ti}_{6} \mathrm{Al}_{4} V$ у водних розчинах тартратної, оксалатної та ичитратної кислот. Формувальні залежності типу $U-f(\tau)$, отримані при проведенні окислення у гальваностатичному режимі, мають лінійну форму, що вказує на формування малопористих оксидних плівок діелектричного типу. Утворенню пасивуючих оксидних плівок бар'єрного типу сприяє незначна травляча дія розчинів карбонових кислот, які належать до слабких електролітів. Встановлено, що зміна напруги на коміриі, яка відображає динаміку утворення оксидної плівки у вигляді формувальної залежності, визначається анодною густиною струму. Швидкість наростання напруги на коміриі збільшується зі зростанням густини струму, щзо випливає зі збільшення швидкості електрохімічного окислення металу. Максимальна для цих умов товщина оксидної плівки визначається величиною кінщевої прикладеної напруги і не залежить від густини струму, природи та концентрації електроліту. Отримані дані пояснюються тим, щзо формування оксиду у гальваностатичному режимі проходить за наявності постійного градієнта потенціалу в оксидній плівці. Збільшення величини прикладеної до комірки напруги зумовлює пропориійне зростання максимальної товщини оксиду, оскільки призводить до збільшення кількості електрики та відповідного їй збільшення маси окисленого металу внаслідок анодної електрохімічної реакиії. Отримані дані дозволяють стверджувати, що вибір електроліту й електричного режиму процесів електрохімічного оксидування сплаву $\mathrm{Ti}_{6} \mathrm{Al}_{4} V$ повинен трунтуватися на результатах дослідження функціональних $i$ захисних властивостей оксидних покриттів

Ключові слова: анодна поляризація, електрохімічне окислення, оксидна плівка, формувальна залежність, градієнт потенціалу, гальваностатичний режим.

Постановка проблемы. Титан является одним из наиболее востребованных металлов современной техники, что вызвано его высокой коррозионной стойкостью и технологичностью. Чистый титан обладает недостаточными прочностными свойствами, поэтому большее применение имеют титановые сплавы. Широкое применение получил сплав $\mathrm{Ti}_{6} \mathrm{Al}_{4} \mathrm{~V}$, который хорошо обрабатывается резанием, имеет высокую удельную прочность. Этот сплав используют для изготовления ответственных деталей, которые должны обладать высокой коррозионной стойкостью. Однако это свойство титановых сплавов, как правило, уменьшается при увеличении числа легирующих элементов [1;2]. Одним из методов повышения коррозионной стойкости является оксидирование, позволяющее сформировать на поверхности сплава пассивные оксидные пленки [3]. Распространенным способом оксидирования является электрохимическое окисление, которое при простом приборном оформлении позволяет получать пленки заданной толщины $[4 ; 5]$.
Исследованию процессов электрохимического оксидирования титана и его сплавов посвящено большое количество работ. Внимание к методу обусловлено тем, что применение электрохимических приемов дает возможность получать пленки различной структуры и широким спектром свойств. Для электрохимического оксидирования используют растворы органических [6; 7], неорганических кислот [8], электролиты, содержащие оба типа кислот или смеси кислот и солей [10-16], щелочи [17].

Перспективным является использование в качестве электролитов веществ, которые, образуя растворы с высокой проводимостью, при растворении в воде одновременно оказывают слабое травящее действие на оксидную пленку, образующуюся при окислении титана. К таким веществам относятся карбоновые кислоты, поэтому данное исследование направлено на изучение процессов формирования оксидных пленок в растворах винной, щавелевой и лимонной кислот. 
В качестве рабочих электродов использовали пластины размером $70 \times 20 \times 5$ мм. Пластины шлифовали наждачной бумагой, обезжиривали водной суспензией $\mathrm{Na}_{2} \mathrm{CO}_{3}$ и травили в смеси $\mathrm{HNO}_{3}$ и $\mathrm{HF}$ (3:1). Оксидирование проводили в гальваностатическом режиме, задавая при помощи источника Б5-50 конечное напряжение на ячейке (10-100 В с шагом 10 В). Напряжение при электролизе измеряли мультиметром Keithley-2000. В качестве электролизера для проведения процесса использовали стакан объемом 250 мл. Для исключения нагрева стакана его размещали в кристаллизаторе объемом 5 л, заполненным водой. Вспомогательным электродом служил свинец. Для проведения исследования использовали реактивы квалификации «ч.».

Изложение основного материала исследования. Исследование динамики оксидирования проводили путем получения формировочных зависимостей $U=f(t)$ на образцах сплава (рис. 1). Определяющее влияние на ход зависимостей имеет анодная плотность тока $j_{\mathrm{a}}$. При значениях $j_{\mathrm{a}}<0,5 \mathrm{~A} \cdot$ дм $^{-2}$ зависимости нелинейны (рис. 1, кривая 1). Заданное значение $U$ не достигается, что обусловлено протеканием двух противоположных процессов, первый из которых заключается в электрохимическом образовании пленки,

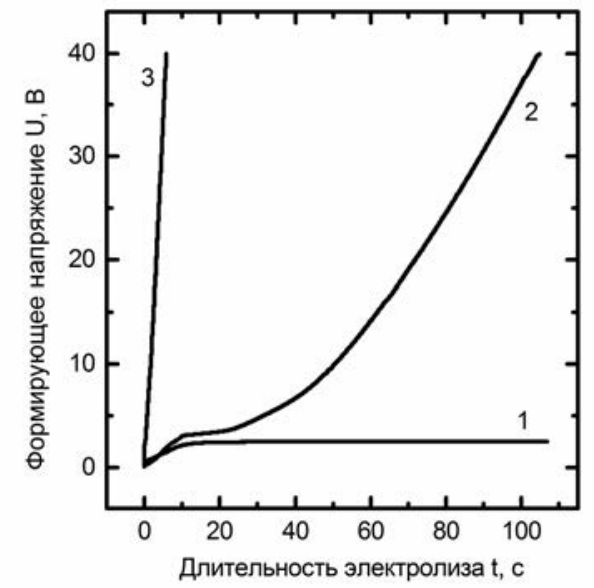

Рис. 1. Формовочные зависимости, полученные при оксидировании сплава в растворах карбоновых кислотах. $j_{\mathrm{a}}, \mathbf{A} \cdot \mathbf{д M}^{-2}: \mathbf{0 , 2}(1) ; 0,5(2) ; 5(3)$. $U=40 \mathrm{~B} ; c_{\mathrm{A}}=50 \boldsymbol{\Gamma}^{\cdot} \mathrm{дM}^{-3}$

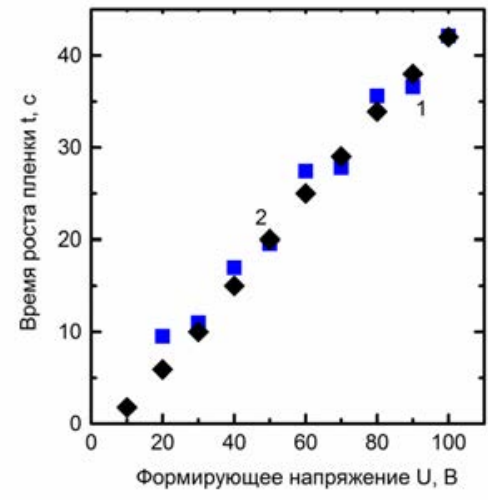

$\sigma$

$a$

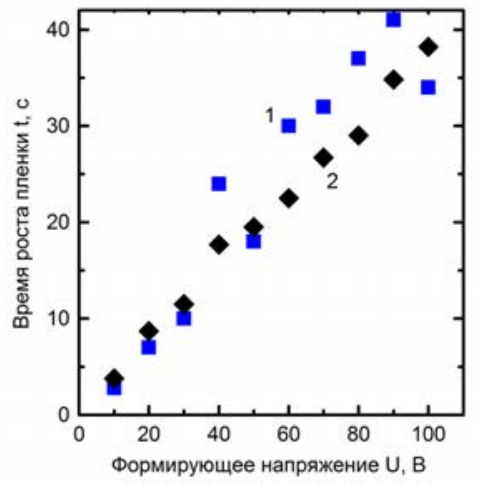

B

Рис. 2. Зависимость времени роста пленки максимальной толщины от напряжения, полученная в растворах винной (a), лимонной (б) и щавелевой (в) кислот. $j_{\mathrm{a}}=2 \mathrm{~A} \cdot$ дм$^{-2} ; c_{\mathrm{A}}, \Gamma^{\circ} \cdot$ дм ${ }^{-3}: 5(1), 10(2), 25(3), 50(4), 100(5)$ 
а второй - в ее химическом растворении. Оксидирование при $j_{\mathrm{a}}=0,5 \mathrm{~A} \cdot$ дм $^{-2}$ приводит к появлению площадки, после которой наблюдается постепенное нарастание напряжения до заданного значения, то есть процесс характеризуется торможением, которое отвечает постепенному заполнению поверхности металла оксидной пленкой.

При оксидировании при $j_{\mathrm{a}}=1-5 \mathrm{~A} \cdot$ дм$^{-2}$ образуются малопористые пленки. На это указывает линейность зависимости $U=f(t)$. Окраска пленки и ее толщина не зависят от природы электролита и определяются заданной величиной напряжения. Характерная зависимость времени достижения максимальной для данных условий толщины пленки $t_{\text {пр }}$ от напряжения сохраняется для всего ряда образцов, оксидированных в одинаковых условиях (рис. 2, $a-8$ ).

Время, необходимое для достижения предельной толщины пленки при оксидировании в гальваностатическом режиме, зависит от формирующего напряжения и линейно возрастает при ее увеличении. При $j_{\mathrm{a}}=2 \mathrm{~A} \cdot$ дм $^{-2}$ линейная зависимость наблюдается для всех исследованных растворов кислот. Величина времени $t$ не зависит от типа используемой кислоты. При повышении значения $U$ наблюдается увеличение длительности электролиза во всех исследованных электролитах (рис. 2). Для ряда одинаковых $j_{\mathrm{a}}$ также наблюдается линейный характер времени выхода $t_{\text {пр }}$ на заданное напряжение (рис. 3). Значение времени $t$ для каждой определенной плотности тока линейно возрастает с увеличением формирующего напряжения и не зависит от концентрации электролита.

Изменение концентрации карбоновой кислоты в пределах 5-100 г· дм ${ }^{-3}$ не влияет на длительность роста пленки, то есть предельная толщина пленки зависит прежде всего от значения формирующего напряжения (рис. 2, а-в).

Таким образом, полученные экспериментальные данные показывают, что определяющее влияние на толщину оксидной пленки имеет величина заданного напряжения. Природа карбоновой кислоты, ее концентрация, плотность тока влияния на толщину пленки не оказывают. Плотность тока влияет на скорость достижения максимальной толщины пленки, так как для электрохимической реакции $j_{\mathrm{a}}$ является ее скоростью.

Движущей силой процесса анодирования является наличие значительной напряженности электрического поля в пленке при анодном окислении. Увеличение толщины пленки прекращается при достижении градиента потенциала, который не может обеспечить перемещение ионов через оксид. При окислении металла в гальваностатическом режиме для поддержания заданного тока необходима постоянная напряженность поля по толщине сформированной пленки [18-21]. Если оксид образуется при $j_{\mathrm{a}}=$ const, напряжение на пленке должно линейно увеличиваться, то есть должно наблюдаться линейное уравнение типа $x=a y$, где $x$ - толщина пленки, $y$ - напряжение формовки, $a-$ коэффициент пропорциональности

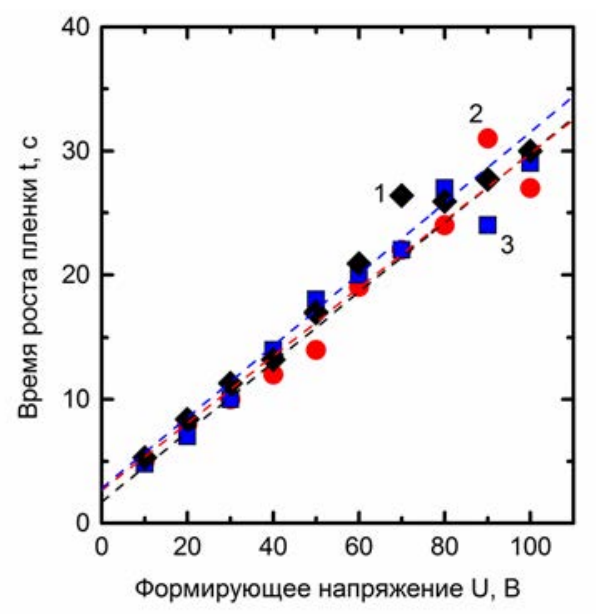

$a$

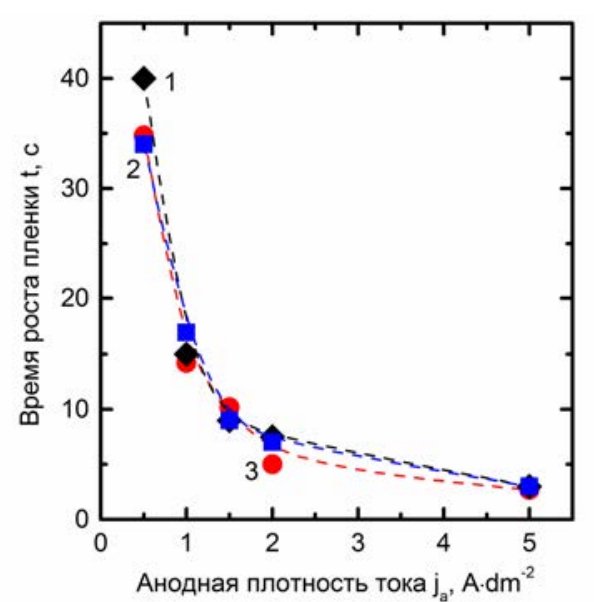

$\sigma$

Рис. 3. Зависимость $t_{\text {пр }}$ от формирующего напряжения (a) и плотности тока оксидирования (б), полученная в щавелевой кислоте. $a-c_{\mathrm{A}}=50 \Gamma \cdot Д \mathrm{M}^{-3} ; j_{\mathrm{a}}, \mathrm{A} \cdot Д \mathrm{M}^{-2}: 1(1), 2(2), 3(3) . \sigma-U=20 \mathrm{~B} ; c_{\mathrm{A}}=50 \Gamma \cdot Д \mathrm{M}^{-3}$ 
(постоянная роста пленки), которая для титана изменяется в пределах $1,9-6,0 \mathrm{Hм} \cdot \mathrm{B}^{-1}[22]$.

Вышеизложенное объясняет экспериментальные результаты. Формовочные зависимости сплава (рис. 1), показывают, что рост $j_{\mathrm{a}}$ способствует повышению скорости формирования оксидной пленки. Линейность зависимостей $U=$ $f(t)$ при $j_{\mathrm{a}}>0,5 \mathrm{~A} \cdot$ дм$^{-2}$ указывает на образование оксида барьерного типа. Такой же вывод можно сделать и на основании данных, приведенных на рис. 2 и 3 . Толщина оксидной пленки, сформированной при $j_{\mathrm{a}}=$ const, зависит только от приложенного напряжения. При $j_{\mathrm{a}}=$ const увеличение напряжения будет увеличивать максимальную толщину оксида или пропорциональную ей длительность электролиза.

Максимальная толщина пленок, полученных в растворах карбоновых кислот при $C_{\mathrm{A}}=5-100 \Gamma \cdot$ дм $^{-3}$ и $j_{\mathrm{a}}>0,5 \mathrm{~A} \cdot$ дм $^{-2}$ в диапазоне $U=10-100 \mathrm{~B}$, определяется только величиной напряжения. Экспериментальные данные указывают на то, что анодная поляризация сплава сопровождается образованием пленок барьерного типа, которые обладают хорошими защитными свойствами из-за большого омического сопротивления $\mathrm{TiO}_{2}$.

Выводы. 1. Исследована динамика образования оксидных пленок на титановом сплаве $\mathrm{Ti}_{4} \mathrm{Al}_{6} \mathrm{~V}$ в растворах карбоновых кислот. Установлено, что определяющее влияние на характер зависимостей $U=f(t)$ имеет значение используемой плотности тока. При $j_{\mathrm{a}}<0,5 \mathrm{~A} \cdot$ дм $^{-2}$ сплошная оксидная пленка не формируется и выхода на заданное напряжение не происходит. При $j_{\mathrm{a}}>0,5 \mathrm{~A} \cdot$ дм$^{-2}$ зависимости $U=f(t)$ линейны, что указывает на образование малопористых пленок. Для исследованных растворов карбоновых кислот наблюдается совпадение формовочных зависимостей сплава, что позволяет предположить одинаковый механизм образования оксидной пленки.

2. Анодная поляризация сплава в растворах карбоновых кислот приводит к формированию на поверхности образцов тонких интерференционно-окрашенных пленок. Показано, что предельная толщина пленки определяется величиной напряжения и не зависит от природы электролита, его концентрации и плотности тока. При электролизе в гальваностатическом режиме наблюдаются линейные зависимости $U=f(t)$ и $t=f(U)$, что указывает на формирование пленок $\mathrm{TiO}_{2}$ барьерного типа. Увеличение плотности тока приводит к более быстрому формированию оксида, хотя линейной зависимости $t=f\left(j_{\mathrm{a}}\right)$ не наблюдается. Полученные результаты объясняются тем, что рост пленки происходит при наличии определенного градиента потенциала, снижение которой приводит к прекращению формирования оксида.

\section{Список литературы:}

1. Adya N., Alam M., Ravindranath T., Mubeen A., Saluja B. Corrosion in titanium dental implants: literature review. J. Indian Prosthodont. Soc. 2005. Vol. 5. P. 126-131.

2. Mohammed M.T., Mohammed, Khan Z.A., Siddiquee A.N. Surface modifications of titanium materials for developing corrosion in human body environment: a review. Proc. Mat. Sci. 2014. Vol. 6. P. 1610-1618.

3. Garg H., Bedi G., Garg A. Implant surface modifiations: a review. J. Clin. Diagn. Res. 2012. Vol. 6. № 2. P. 319-324.

4. Liu X., Chu P., Ding C. Surface modification of titanium, titanium alloys, and related materials for biomedical applications. Mat. Sci. Eng.: R. Reports. 2004. Vol. 47. Iss. 3-4. P. 49-121.

5. Pilipenko A., Pancheva H., Deineka V., Vorozhbiyan R., Chyrkina M. Formation of oxide fuels on VT6 alloy in the conditions of anodial polarization in solutions $\mathrm{H}_{2} \mathrm{SO}_{4}$. EEJET. 2018. Vol. 3. № 6. P. 33-38.

6. Yan Z.M., Guo T.W., Pan H.B., Yu J.J. Influence of electrolyzing voltage on chromatics of anodizes titanium dentures. Mater. Trans. 2002. Vol. 43. № 12. P. 3142-3145.

7. Diamanti M.V., Curto B.D., Masconale V., Passaro C., Pedeferri M.P. Anodic coloring of titanium and its alloy for jewels production. Color Res. Appl. 2012. Vol. 37. Iss. 5. P. 384-390.

8. Gaul E. Coloring titanium and related metals by electrochemical oxidation. J. Chem. Edu. 1993. Vol. 70. Iss. 3. P. 176-179.

9. Shibata T., Zhu Y.C. The effect of film formation conditions on the structure and composition of anodic oxide films on titanium. Corrosion Sci. 1995. Vol. 37. Iss. 2. P. 253-270.

10. Diamanti M.V., Curto B.D., Pedeferri M.P. Interference colors of thin oxide layers on titanium. Color Res. Appl. 2007. Vol. 33. Iss. 3. P. 221-228.

11. Lu J., Wei G., Yu.Y., Zhao X., Dai Y. Enhanced corrosion resistance of TA2 titanium via anodic oxidation in mixed acid system. Int. J. Electrochem. Sci. 2017. Vol. 12. P. 2763-2776.

12. Napoli G., Paura M., Vela T., Schino A.D. Coloring titanium alloys by anodic oxidation. Metalurgija. 2018. Vol. 57. Iss. 1-2. P. 111-113.

13. Hamouda I.M., El-wassefy N.A., Marzook H.A., El-deen A.N., Habib A., El-awady G.Y. Micro-photographic analysis of titanium anodization to assess bio-activation. Eur. J. Biotech. Biosci. 2014. Vol. 1. Iss. 3. P. 17-26. 
14. Choudhary R.K., Sarkar P., Biswas A., Mishra P., Abraham G.J., Sastry P.U., Kain V. Structure, morphology and optical properties of $\mathrm{TiO}_{2}$ films formed by anodizing in a mixed solution of citric acid and sulfamic acid. J. Mater. Eng. Perf. 2017. Vol. 26. Iss. 8. P. 4001-4010.

15. Schmidt A.M., Azambuja D.S. Electrochemical behavior of Ti and Ti6A14V in aqueous solutions of citric acid containing halides. Mat. Res. 2006. Vol. 9. № 4. P. 387-392.

16. Liang H., Liu J., Wu L., Li X., Zhu M. Effect of tartaric acid on anodic behaviour of titanium alloy. Surf. Eng. 2015. Vol. 31. Iss. 12. P. 912-918.

17. Sul Y.-T., Johansson C.B., Jeong Y., Albrektsson T. The electrochemical oxide growth behaviour on titanium in acid and alkaline electrolytes. Med. Eng. \& Phys. 2001. Vol. 23. Iss. 5. P. 329-346.

18. Ivashchenko M., Smirnova O., Kyselova S., Avina S., Sincheskul A., Pilipenko A. Establishing the patterns in the formation of films on the alloy Ti6A14V in carbonic acid solutions. EEJET. 2018. Vol. 5. № 6. P. 21-26.

19. Pilipenko A., Maizelis A., Pancheva H., Zhelavska Y. Electrochemical oxidation of VT6 titanium alloy in oxalic acid solutions. Chem. Chem. Techn. 2020. Vol. 14. Iss. 2. P. 221-226.

20. Pilipenko A., Smirnova O., Gura S., Skorynina-Pohrebna O., Khoroshev O., Shkolnikova T. Studying the insulating properties of oxide films obtained on the Ti6A14V alloy in tartaric acid solutions using the method of electrochemical decoration by copper. ARPN Journal of Engineering and Applied Sciences. 2020. Vol. 15. № 15. P. 1657-1666.

21. Shevchenko G., Pilipenko A., Shkolnikova T., Gura S., Smirnova O. Production of nanosize interferencecolored oxide films on the Ti6A14V alloy surface using the method of electrochemical oxydation in succinate eletrolytes. 2020 IEEE 40 th International Conference on Electronics and Nanotechnology, ELNANO-2020. Proceedings. P. 216-219.

22. Aladjem A. Anodic oxidation of titanium and its alloy. J. Mater. Sci. 1973. Vol. 29. Iss. 5. P. 688-704.

\section{Smirnova O.L., Pylypenko O.I. ELECTROCHEMICAL OXIDATION OF THE $\mathrm{TI}_{6} \mathbf{A L}_{4} \mathrm{~V}$ ALLOY IN THE SOLUTIONS OF CARBOXYLIC ACIDS}

The research data of the processes of the electrochemical oxidation of the $T_{6}{ }_{6} A l_{4} V$ alloy in the solutions of tartaric, oxalic and citric acids have been given. The molding dependences of the type $U-f(\tau)$ that were obtained through the oxidation in the galvanostatic mode have a linear form and it is indicative of the formation of the low porosity oxide films of a dielectric type. The formation of the films of a barrier type is facilitated by a slight etching action of the solutions of carboxylic acids that are weak electrolytes. It was established that a change in the cell voltage that reflects the oxide film formation dynamics in the form of molding dependence is defined by the anode current density. The cell voltage rising rate is increased with an increase in the current density that follows from an increase in the rate of the electrochemical metal oxidation. A maximum thickness of oxide film for the given conditions is defined by the value of applied terminal voltage and it is not dependent on the current density, the electrolyte nature and its concentration. The obtained data are explained by that the formation of oxide in the galvanostatic mode occurs in the conditions of the availability of a constant potential gradient in the oxide film. An increase in the value of voltage applied to the cell conditions a proportional growth of a maximum oxide thickness, because it results in an increased quantity of electricity and appropriate increase in the mass of oxidized metal. The obtained data allow us to state that the choice of electrolyte and the electric mode of the processes of the electrochemical oxidation of the $\mathrm{Ti}_{6} \mathrm{Al}_{4} \mathrm{~V}$ alloy should be based on the research data of the functional and protective properties of oxide coatings.

Key words: anodic polarization, electrochemical oxidation, oxide film, formation dependence, potential gradient, galvanostatic mode. 